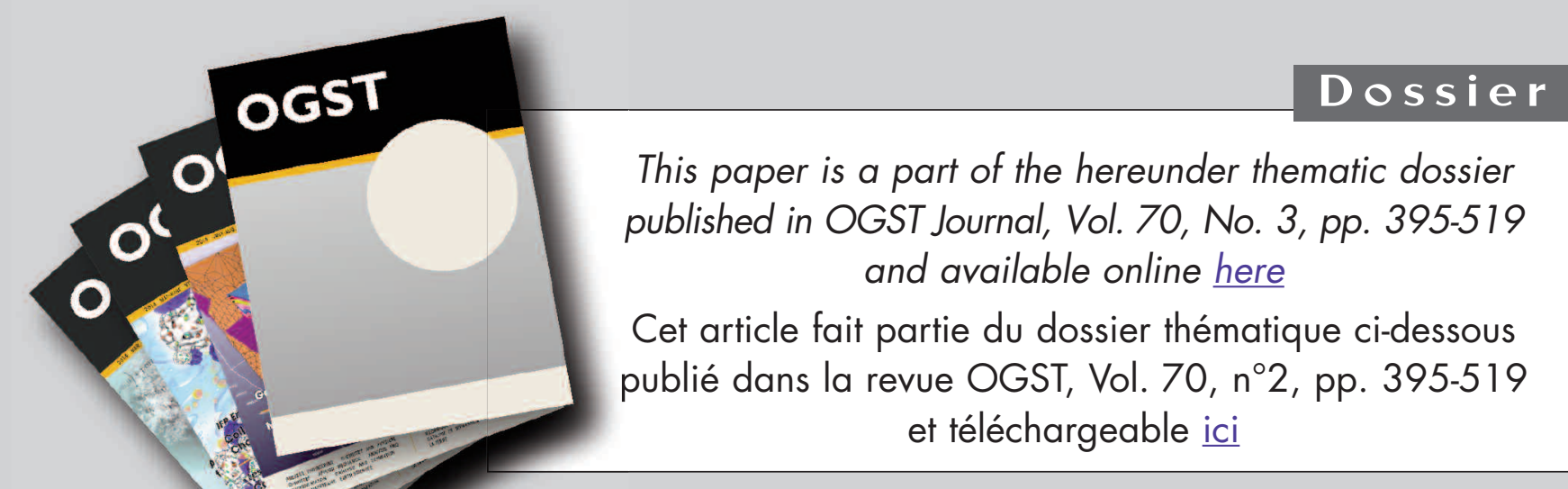

DOSSIER Edited by/Sous la direction de : V. Santos-Moreau

IFP Energies nouvelles International Conference / Les Rencontres Scientifiques d'IFP Energies nouvelles NEXTLAB 2014 - Advances in Innovative Experimental Methodology or Simulation Tools used to Create, Test, Control and Analyse Systems, Materials and Molecules

NEXTLAB 2014 - Innover dans le domaine de la méthodologie expérimentale et des outils de simulation pour créer, tester, contrôler et analyser des systèmes, matériaux et molécules

Oil \& Gas Science and Technology - Rev. IFP Energies nouvelles, Vol. 70 (2015), No. 3, pp. 395-519

Copyright (C) 2015, IFP Energies nouvelles

$395>$ Editorial - Towards the Laboratory of the Future for the Factory of the Future Éditorial - Vers le laboratoire du futur pour construire l'usine du futur V. Santos-Moreau, J.M. Newsam and J.-C. Charpentier

$405>$ Automatic and Systematic Atomistic Simulations in the MedeA ${ }^{\circledR}$ Software Environment: Application to EU-REACH

Simulations atomistiques automatiques et systématiques dans l'environnement logiciel de MedeA® : application à EU-REACH

$X$. Rozanska, P. Ungerer, B. Leblanc, P. Saxe and E. Wimmer

419 > Development of an Innovative XRD-DRIFTS Prototype Allowing Operando Characterizations during Fischer-Tropsch Synthesis over Cobalt-Based Catalysts under Representative Conditions

Développement d'un prototype DRX-DRIFTS innovant permettant des caractérisations operando de catalyseurs à base de cobalt pendant la synthèse de Fischer-Tropsch en conditions représentatives

J. Scalbert, I. Clémençon, C. Legens, F. Diehl, D. Decottignies and S. Maury

429 > Synchrotron X-ray Scattering as a Tool for Characterising Catalysts on Multiple Length Scales

La diffusion des rayons $X$ synchrotron : un outil pour la caractérisation des catalyseurs sur les multiples échelles de longueur

J.M. Hudspeth, K.O. Kvashnina, S.A.J. Kimber and E.P. Mitchell

437 > High Throughput Experimentation (HTE) Directed to the Discovery,

Characterization and Evaluation of Materials

Expérimentation à haut débit pour la découverte, la caractérisation et

l'évaluation des matériaux

J.M. Newsam

447 > The Use of Original Structure-Directing Agents for the Synthesis of EMC-1 Zeolite L'utilisation d'agents structuraux originaux pour la synthèse de zéolithe EMC-1

T.J. Daou, J. Dhainaut, A. Chappaz, N. Bats, B. Harbuzaru, H. Chaumeil, A. Defoin,

L. Rouleau and J. Patarin
455 > REALCAT: A new Platform to Bring Catalysis to the Lightspeed REALCAT : une nouvelle plate-forme pour mener la catalyse à la vitesse de la lumière

S. Paul, S. Heyte, B. Katryniok, C. Garcia-Sancho, P. Maireles-Torres and F. Dumeignil

$463>$ What are the Needs for Process Intensification? Quels besoins pour intensifi er un procédé ?

C. Gourdon, S. Elgue and L. Prat

$475>$ Revisiting the Side Crushing Test Using the Three-Point Bending Test for the Strength Measurement of Catalyst Supports

Test d'écrasement grain à grain revisité à l'aide du test de flexion trois points pour la mesure de la résistance des supports de catalyseurs D. Staub, S. Meille, V. Le Corre, J. Chevalier and L. Rouleau

487 > Refractometric Sensing of Heavy Oils in Fluorescent Core Microcapillaries La détection réfractométrique des huiles lourdes dans les microcapillaires à cœur fluorescents

V. Zamora, Z. Zhang and A. Meldrum

497 > Two-Phase Flow in Pipes: Numerical Improvements and Qualitative Analysis for a Refining Process

Écoulements diphasiques dans les conduites : améliorations numériques et analyse qualitative pour un procédé de raffinage

R.G.D. Teixeira, A.R. Secchi and E.C. Biscaia Jr

511 > Comparative TPR and TPD Studies of Cu and Ca Promotion on Fe-Zn- and Fe-Zn-Zr-Based Fischer-Tropsch Catalysts

Études comparatives par TPR et TPD de la promotion par Cu et Ca de I'activité de catalyseurs Fischer-Tropsch Fe-Zn et Fe-Zn-Zr 0.0 . James, B. Chowdhury and S. Maity 
NEXTLAB 2014 - Advances in Innovative Experimental Methodology or Simulation Tools used to Create, Test, Control and Analyse Systems, Materials and Molecules

\title{
Development of an Innovative XRD-DRIFTS Prototype Allowing Operando Characterizations during Fischer-Tropsch Synthesis over Cobalt-Based Catalysts under Representative Conditions
}

\author{
Julien Scalbert, Isabelle Clémençon, Christèle Legens*, Fabrice Diehl, \\ Dominique Decottignies and Sylvie Maury \\ IFP Energies nouvelles, Rond-point de l'échangeur de Solaize, 69360 Solaize - France \\ e-mail: christele.legens@ifpen.fr \\ * Corresponding author
}

\begin{abstract}
An original system combining both X-Ray Diffraction and diffuse reflectance infrared Fourier transform spectroscopy was developed with the aim to characterize Fischer-Tropsch catalysts in relevant reaction conditions. The catalytic properties of a model PtCo/silica catalyst tested with this prototype have shown to be in the same range of those obtained in similar conditions with classical fixed-bed reactors. No bulk cobalt oxidation nor sintering were observed on operando XRD patterns. The formation of linear carbonyls and adsorbed hydrocarbons species at the surface of the catalyst was observed on operando DRIFT spectra. The surface of the catalyst was also suspected to be covered with carbon species inducing unfavorable changes in selectivity.
\end{abstract}

Résumé - Développement d'un prototype DRX-DRIFTS innovant permettant des caractérisations operando de catalyseurs à base de cobalt pendant la synthèse de Fischer-Tropsch en conditions représentatives - Un système original combinant diffraction des rayons $\mathrm{X}$ et spectroscopie infrarouge à réflexion diffuse a été développé dans le but de caractériser des catalyseurs de Fischer-Tropsch dans des conditions réactionnelles pertinentes. Les propriétés catalytiques d'un catalyseur modèle de type $\mathrm{PtCo} /$ silice testé avec ce prototype étaient similaires à celles obtenues dans des conditions équivalentes avec des réacteurs classiques à lit fixe. Ni oxydation du cobalt ni frittage n'ont été observés sur les diagrammes de diffraction operando. La formation de carbonyles linéaires et d'hydrocarbures adsorbés à la surface du catalyseur a été observée sur les spectres DRIFT operando. La formation d'espèces carbonées à la surface du catalyseur est soupçonnée d'induire des changements défavorables au niveau de la sélectivité. 


\section{INTRODUCTION}

Fischer-Tropsch synthesis could be an appropriate solution to the crucial need for diversification of fuel sources. Fischer-Tropsch reaction consists in converting syngas (mixture made of $\mathrm{CO}$ and $\mathrm{H}_{2}$ ) obtained from natural gas (GTL, Gas To Liquids), coal (CTL, Coal To Liquids) or biomass (BTL, Biomass To Liquids) into hydrocarbons of high purity which can also contribute to lower rates of undesirable elements in the gasoline and Diesel pools. Supported cobalt catalysts are known to be efficient Fischer-Tropsch catalysts for high molecular weight hydrocarbons production, and are already used in industrial-scale processes [1-3].

However the reaction mechanism of the FischerTropsch synthesis as well as the possible pathways leading to deactivation are quite unclear and still subjects to intense discussion $[4,5]$. For instance, many hypotheses have been proposed to explain catalyst deactivation, and among them phenomena such as cobalt oxidation $[5,6]$, sintering $[5,7]$ or coke formation $[5,8]$.

To better understand what really occurs during the reaction, we developed an innovative XRD-DRIFTS prototype allowing operando characterizations of the structure and the surface of catalysts during FischerTropsch synthesis under representative reaction conditions (high pressure, high temperature).

Operando methodology has indeed proven to be very helpful and powerful in unraveling reaction mechanisms and evidencing deactivation phenomena [9-11].

\section{EXPERIMENTAL}

\subsection{XRD-DRIFTS Prototype}

An original system combining a X-Ray Diffractometer and a DRIFT spectrometer was developed to allow simultaneous XRD (X-Ray Diffraction) and IR (InfraRed) in situ characterizations of catalysts (Fig. 1). A gas chromatograph was added to analyze the composition of the inlet and outlet gases, which allows operando studies of catalytic reactions carried out inside an optimally-designed reaction cell in a fixed-bed configuration.

\subsubsection{XRD Part of the System}

The XRD part of the apparatus consists in an INEL X-Ray Diffractometer in a Debye-Scherrer configuration, fitted with a molybdenum tube $\left(\lambda_{\mathrm{K} \alpha 1}=0.7090 \AA\right)$ in transmission mode and a curved detector (INEL CPS 120) [12]. The molybdenum tube provides energetic X-Rays, which makes possible the characterization of thick samples under absorbing atmospheres. The curved detector allows the collection of a wide range $\left(120^{\circ}-2 \theta\right)$ of the diffracted X-Rays without moving the sample or the detector itself, which induces a quite large gain in analysis time and a non-negligible simplification in the prototype design. The beryllium windows on the path of the X-Ray beam permit transmission while maintaining the sealing and the resistance of the reaction cell.

\subsubsection{DRIFTS Part of the System}

The DRIFTS part of the apparatus consists in an infrared spectrophotometer (Bruker IRcube OEM FT-IR) fitted with a liquid- $\mathrm{N}_{2}$ cooled MCT (Mercury-CadmiumTelluride) detector. A set of mirrors in an appropriate geometric configuration allows the reflection of the IR beam from the source to the surface of the sample where the subsequent diffuse IR radiation is then reflected to the detector. Thick ZnSe windows are used to allow an optimal transmission of the IR beam while also maintaining the sealing and the resistance of the cell. $\mathrm{ZnSe}$ material allows IR transmission in the range $12000-600 \mathrm{~cm}^{-1}$ with a refractive index of 2.4 (at $1000 \mathrm{~cm}^{-1}$ ). Despite its higher refractive index, $\mathrm{ZnSe}$ was preferred to $\mathrm{KBr}$, because $\mathrm{ZnSe}$ is insoluble in water and resistant to organic solvents. Since water is the main product of the Fischer-Tropsch reaction, it was essential that the windows remain inert towards water to avoid any degradation of the cell sealing during the reaction. However, carbon monoxide being a strongly IR absorbing medium, the partial pressure of $\mathrm{CO}$ reactant was limited to 2 bar inside the cell to get workable quality DRIFT spectra.

\subsubsection{Operando Cell}

The reaction cell was especially designed to carry out catalytic reactions in a fixed-bed-like configuration, while simultaneously characterizing the catalyst with XRD and DRIFTS.

For a typical XRD-DRIFTS operando study, the sample is placed on a porous silica fritted disc, located in an inox cylinder around which is rolled, a heating resistor acting as a furnace. This furnace allows working at temperatures as high as $600^{\circ} \mathrm{C}$. A thermocouple in close contact with the sample is used to regulate the temperature.

Fischer-Tropsch synthesis being a high-pressure process, the cell was manufactured to be used under pressure up to 18 bar. The structure of the cell is made of stainless steel and the Be and $\mathrm{ZnSe}$ windows are thick enough to support such pressures.

The reactant gas mixture flows in the cell passing through the catalyst powder from the top to the bottom 

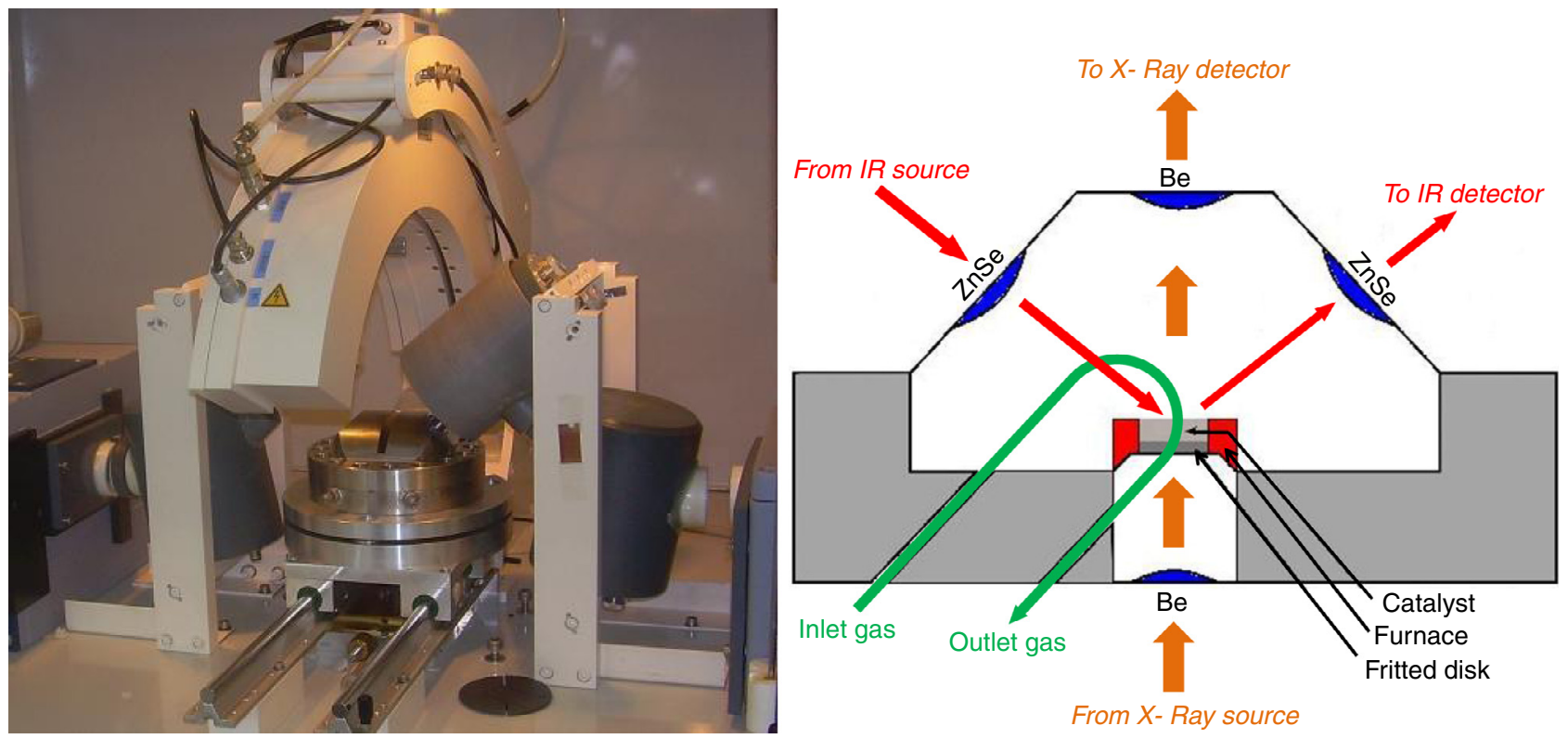

a)

b)

Figure 1

a) Picture of the XRD-DRIFTS apparatus and b) scheme of the reaction cell.

of the bed. The lines are heated at $120^{\circ} \mathrm{C}$ to prevent any condensation of reaction products. The outlet gas containing reaction products flows then to a condenser kept at $15^{\circ} \mathrm{C}$ where the heaviest products condense to liquid or solid form (wax) depending on their boiling point. The lightest compounds (up to $\mathrm{C}_{12}$ ) are expelled to the hood or analyzed through a Gas Chromatography (GC).

\subsubsection{On-Line Gas Analysis}

The outlet gas can be analyzed on-line by GC. Hydrocarbons are separated using a PONA column and detected with a Flame Ionized Detector (FID). The detection and quantification of $\mathrm{CO}, \mathrm{CO}_{2}$ and $\mathrm{N}_{2}$ are performed using PPU and MS5A columns with a Thermal Conductivity Detector (TCD), while PPQ and MS5A columns associated with another TCD allow $\mathrm{H}_{2}$ quantification.

A gas flow meter at the outlet of the XRD-DRIFTS system allows measuring the volume of gas flowing out of the cell. This, combined to the concentration of each compound obtained with GC, allows determining the molar quantity of products and of unreacted $\mathrm{CO}$ in the outlet gas. This is in particular useful and essential for calculating $\mathrm{CO}$ conversion (see further about calculations).

\subsubsection{Off-Line Wax Analysis}

As previously written, the heaviest reaction products were condensed to their liquid or solid state (wax) in a condenser cooled at $15^{\circ} \mathrm{C}$. After a typical experiment, the condenser is opened and wax characterized with ex situ GC analysis allowing the identification of heavy hydrocarbons.

\subsection{Catalyst Preparation and Ex Situ Characterization}

Silica with high surface area was prepared by calcination of a commercial silica gel (Grace Davison, Davisil grade 634) at $900^{\circ} \mathrm{C}$ during 4 hours under stagnant air. The obtained silica was then used as a carrier and the model $\mathrm{PtCo} /$ silica catalyst was obtained using an incipient wetness impregnation in two steps.

During the first impregnation step, the silica support was impregnated with a cobalt solution obtained by dissolving $\mathrm{Co}\left(\mathrm{NO}_{3}\right)_{2} \cdot 6 \mathrm{H}_{2} \mathrm{O}$ in water and ethylene glycol. Ethylene glycol was used with the aim to favor cobalt dispersion as reported by Borg et al. [13]. The obtained material was then dried at $85^{\circ} \mathrm{C}$ overnight and calcined under air flow at $420^{\circ} \mathrm{C}$ for 4 hours.

During the second impregnation step, the obtained $\mathrm{Co} /$ silica catalyst was impregnated with a solution 
containing both cobalt (cobalt nitrate) and platinum (tetraammineplatinum hydroxide) precursors in order to achieve a catalyst with a cobalt loading of around $13 \mathrm{wt} \%$ and a platinum content of around $500 \mathrm{ppm}$. The catalyst was afterwards dried and calcined under air flow at $420^{\circ} \mathrm{C}$ during 4 hours.

Cobalt loading was checked by wavelength dispersive X-Ray Fluorescence (XRF) and platinum content by Inductively Coupled Plasma and Optical Emission Spectrometry (ICP-OES).

\subsection{Catalytic Test and Operando Characterizations}

To perform the operando study, about $220 \mathrm{mg}$ of the $\mathrm{PtCo} /$ silica catalyst was placed on a quartz fritted disk inside the reaction cell of the XRD-DRIFTS prototype and reduced at $500^{\circ} \mathrm{C}$ during 16 hours under a flow of 1 L.h ${ }^{-1}$ of pure $\mathrm{H}_{2}$. Before switching to an $\mathrm{H}_{2}+\mathrm{CO}$ flowrate (Fischer-Tropsch synthesis), the cell was cooled down to $220^{\circ} \mathrm{C}$, flushed with $\mathrm{N}_{2}$ and inflated to 6 bar pressure. The catalytic test was then carried out at $220^{\circ} \mathrm{C}, 6$ bar, under a $0.6 \mathrm{~L} . \mathrm{h}^{-1}$ flow made of $\mathrm{H}_{2}$ and $\mathrm{CO}$ in a mixture molar ratio of 2.

Operando X-Ray measurements were carried out every 4 hours with a duration record of 1 hour.

Operando DRIFT spectra were recorded at a resolution of $4 \mathrm{~cm}^{-1}$ and 2048 scans accumulation (duration about $5 \mathrm{~min}$ ) at different times of the reaction. DRIFT spectra are plotted in units of logarithm inverse reflectance. This pseudo-absorbance gives a better linear representation of the band intensity against surface coverage than that given by the Kubelka-Munk function for strongly absorbing media $[9,14]$.

\subsection{Calculations}

The conversion $X_{\mathrm{CO}}$ was defined as $\mathrm{CO}$ conversion, as expressed in Equation (1):

$$
X_{\mathrm{CO}}(\%)=100 \times \frac{\left(n_{\mathrm{CO}}\right)_{\text {in }}-\left(n_{\mathrm{CO}}\right)_{\text {out }}}{\left(n_{\mathrm{CO}}\right)_{\text {in }}}
$$

where $\left(n_{\mathrm{CO}}\right)_{\text {in }}$ and $\left(n_{\mathrm{CO}}\right)_{\text {out }}$ are the molar flow rates of $\mathrm{CO}$ in and out of the reactor respectively.

Selectivity was calculated on a carbon molar basis, as expressed in Equation (2):

$$
S_{j}(\%)=100 \times \frac{i \times n_{j}}{\left(n_{\mathrm{CO}}\right)_{\text {in }}-\left(n_{\mathrm{CO}}\right)_{\text {out }}}
$$

where $S_{j}$ is the selectivity in a $j$ product containing $i$ carbon atoms, and $n_{j}$ is the molar flow rate of the product $j$ out of the reactor.
The yield $\eta_{j}$ in a $j$ product was calculated according to Equation (3):

$$
\eta_{j}(\%)=\frac{X_{\mathrm{CO}} \times S_{j}}{100}
$$

The TurnOver Frequency (TOF) was defined as the molar quantity of converted $\mathrm{CO}$ per mole of surface cobalt atoms per second (Eq. 4):

$$
\operatorname{TOF}\left(\mathrm{mol}_{\mathrm{CO}} \cdot \mathrm{mol}_{\mathrm{Cosurf}}{ }^{-1} \cdot \mathrm{s}^{-1}\right)=\frac{X_{\mathrm{CO}} \times\left(n_{\mathrm{CO}}\right)_{\text {in }}}{100 \times n_{\mathrm{Cosurf}}}
$$

where $\left(n_{\mathrm{CO}}\right)_{\text {in }}$ is expressed in mol.s ${ }^{-1}$, and the molar quantity of surface cobalt atoms in the catalyst $n_{\text {Cosurf }}$ in mol. This value was directly estimated from cobalt loading and dispersion as expressed in Equation (5):

$$
n_{\text {Cosurf }}=\frac{m_{\text {catalyst }} \times \% \mathrm{Co} \times D}{M(\mathrm{Co}) \times 10000}
$$

where $m_{\text {catalyst }}$ expressed in $\mathrm{g}$ is the quantity of catalyst used for the test, \%Co expressed in wt $\%$ is the cobalt content of the catalyst, $D$ expressed in $\%$ is the cobalt dispersion, and $M(\mathrm{Co})$ expressed in $\mathrm{g} \cdot \mathrm{mol}^{-1}$ is the molar mass of cobalt.

In the case of a catalyst not totally reduced, TOF calculation was corrected by taking into account the cobalt reduction degree $\left(\tau_{\mathrm{Co}}\right)$. This new method, assuming that global reduction degree is similar in the bulk and at the surface of cobalt particles, leads to a corrected TOF expressed as $T O F_{\text {corr }}$ in Equation (6):

$$
\text { TOF } \text { corr }\left(\mathrm{mol}_{\mathrm{CO}} \cdot \mathrm{mol}_{\mathrm{Cosurf}}{ }^{-1} \cdot \mathrm{s}^{-1}\right)=\frac{X_{\mathrm{CO}} \times\left(n_{\mathrm{CO}}\right)_{\text {in }}}{n_{\mathrm{Cosurf}}} \times \frac{1}{\tau_{\mathrm{Co}}}
$$

where $\tau_{\mathrm{Co}}$ expressed in $\%$ is the cobalt reduction degree of the catalyst. This value was estimated from the quantification of cobalt oxide and metal cobalt phases on XRD patterns.

\section{RESULTS AND DISCUSSION}

\subsection{Catalyst Ex Situ Characterizations}

Table 1 lists the cobalt and platinum contents of the calcined $\mathrm{PtCo}$ /silica catalyst obtained from XRF and ICPOES ex situ techniques respectively. 
TABLE 1

Main characteristics of the $\mathrm{PtCo} /$ silica catalyst

\begin{tabular}{c|c|c|c}
\hline $\begin{array}{c}\text { Co content } \\
(\mathrm{wt} \%)\end{array}$ & $\begin{array}{c}\text { Pt content } \\
(\mathrm{ppm})\end{array}$ & $\begin{array}{c}\text { Average } \\
\text { particle size } \\
(\mathrm{nm})\end{array}$ & $\begin{array}{c}\text { Cobalt } \\
\text { dispersion } \\
(\%)\end{array}$ \\
\hline $11.6 \pm 0.4$ & $230 \pm 23$ & $13.1 \pm 1.3$ & $7.3 \pm 0.8$ \\
\hline
\end{tabular}

Average $\mathrm{Co}_{3} \mathrm{O}_{4}$ particle size was determined using the Scherrer equation [15] from the most intense $\mathrm{Co}_{3} \mathrm{O}_{4}$ diffraction peak at $d=0.244 \mathrm{~nm}$ observed on the in situ diffraction pattern of the catalyst before reduction. As the molar volume ratio of $\mathrm{Co}$ to $\mathrm{Co}_{3} \mathrm{O}_{4}$ is 0.75 , the average metal cobalt particle size was easily estimated from the average $\mathrm{Co}_{3} \mathrm{O}_{4}$ particle size. This method for estimating cobalt particle size is widely used to avoid errors in the X-Ray analysis of reduced cobalt catalysts [16].

From this average particle size, dispersion was subsequently determined as usually done in the literature dealing with cobalt Fischer-Tropsch catalysts $[13,17]$.

From these results, the number of cobalt atoms at the surface of the catalyst was estimated around 0.14 mmol.g cat $^{-1}$.

\subsection{In situ Monitoring of the Activation Step}

The XRD-DRIFTS apparatus allows monitoring the structure and surface evolution of the catalyst during the activation step. XRD is particularly helpful to follow the crystalline phases changes and to quantify the metal cobalt content (Fig. 2).

Before reduction, $\mathrm{Co}_{3} \mathrm{O}_{4}$ was as expected the only crystalline phase observed. During the reduction, $\mathrm{Co}_{3} \mathrm{O}_{4}$ was successively transformed into $\mathrm{CoO}$ and $\mathrm{Co}$.

After the reduction step, except a small amount of residual $\mathrm{CoO}(\leq 10 \%)$, the catalyst consisted mainly in two crystalline phases: face-centered cubic metal cobalt (fcc $\mathrm{Co}$ ) and hexagonal close packed metal cobalt (hcp Co) [18]. It is important to point out that the experimental diffraction pattern could not be defined as a simple mathematical mixture of model fcc and hcp diagram patterns, as illustrated in Figure 3.

It is thus difficult to quantify each phase according to a classical model based on a simple mathematical equation. This means that the catalyst does not consist in separated pure fcc and hep cobalt particles which would be physically mixed, but more likely in cobalt particles with crystallographic defects alternating fcc and hcp crystalline structures. As illustrated in Scheme 1, fcc and hcp structures differ only in the atoms packing, the former being defined with a "ABCABC" stacking sequence whereas the latter is defined with a "ABAB" sequence.

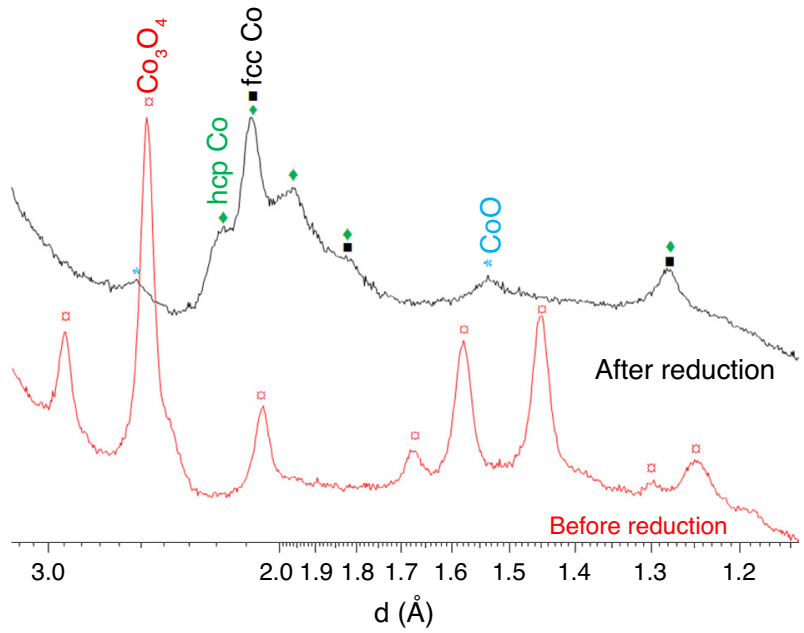

Figure 2

In situ XRD patterns of the $\mathrm{PtCo} /$ silica catalyst recorded before and after the reduction step $\left({ }^{\circ} \mathrm{Co}_{3} \mathrm{O}_{4} ; * \mathrm{CoO}\right.$;

口 fcc Co; $\diamond$ hcp Co).

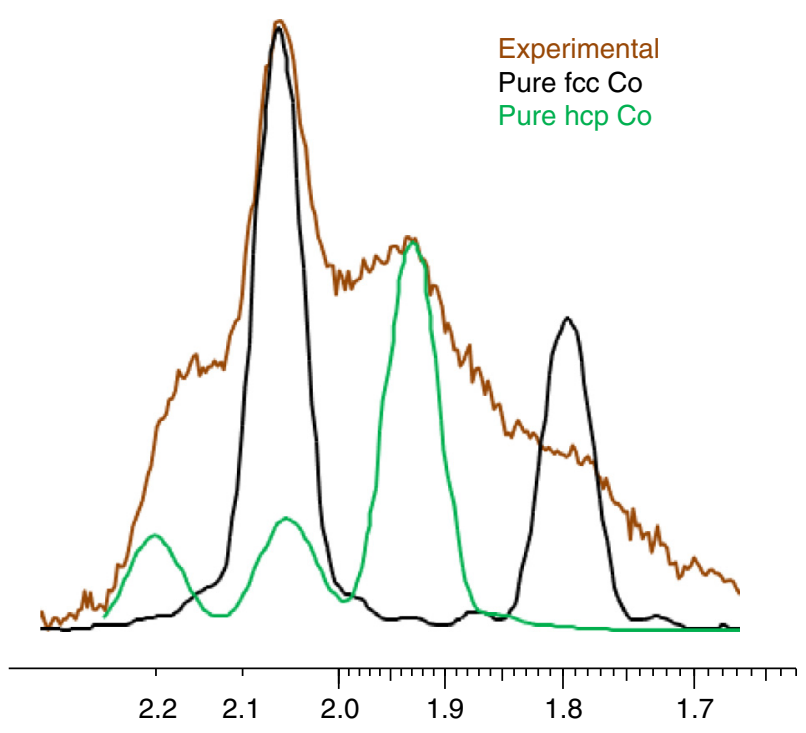

Figure 3

Experimental diffraction pattern compared with a modeled diagram obtained with a mathematical mixture of fcc and hcp phases.

Because of stacking faults, both sequences can appear within a same particle, thus leading to defect particles with alternating fcc and hcp phases linked with atoms belonging to both structures. A new method for XRD signal modeling is being developed to allow cobalt phases quantification and will be the object of a future 


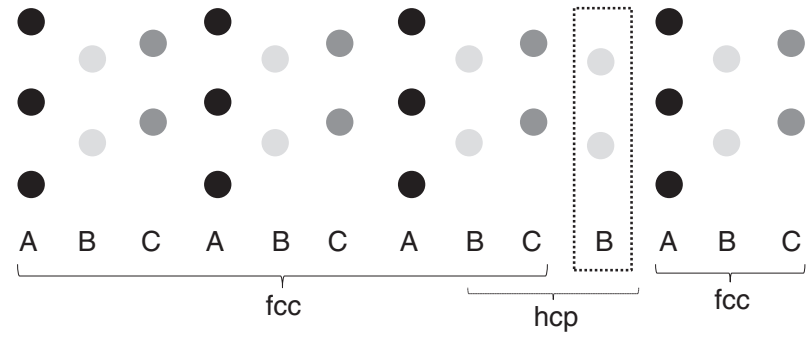

Scheme 1

Representation of stacking faults between fcc and hcp structures.

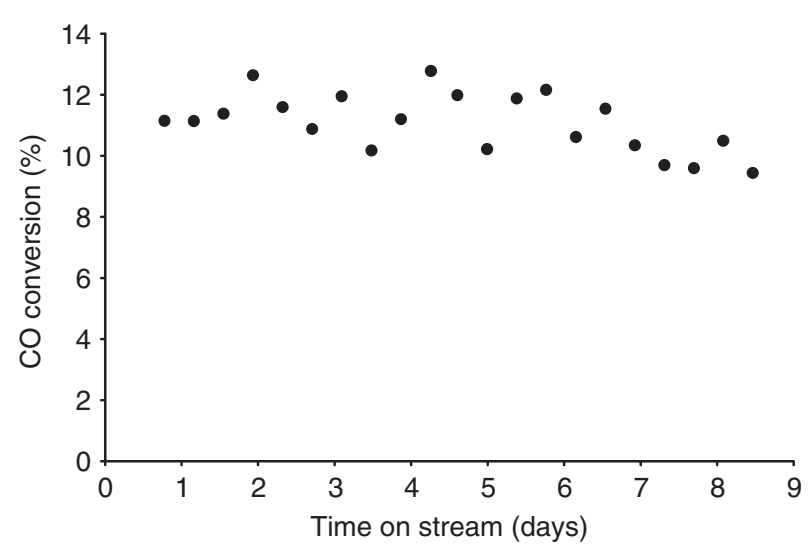

Figure 4

Conversion versus time on stream over $\mathrm{PtCo} /$ silica catalyst. $220^{\circ} \mathrm{C}, 6$ bar, $\mathrm{H}_{2} / \mathrm{CO}=2$.

dedicated article since it is beyond the scope of the present one.

\subsection{Catalytic Properties}

$\mathrm{CO}$ conversion was followed with time on stream during nine days (Fig. 4). During the first hours of the reaction, syngas was progressively replacing $\mathrm{N}_{2}$ in the cell. The removal of $\mathrm{N}_{2}$ from the cell was directly monitored by GC which showed that $\mathrm{N}_{2}$ content in the outlet gas was below $2 \%$ after 10 hours. CO conversion and products selectivity results were here focused on the steady state regime, after 10 hours, with stable and uniform gas composition in the reaction cell.

Over the test duration, conversion was not completely stabilized but more or less oscillating between 10 and $13 \%$. However, it was globally slightly decreasing, from

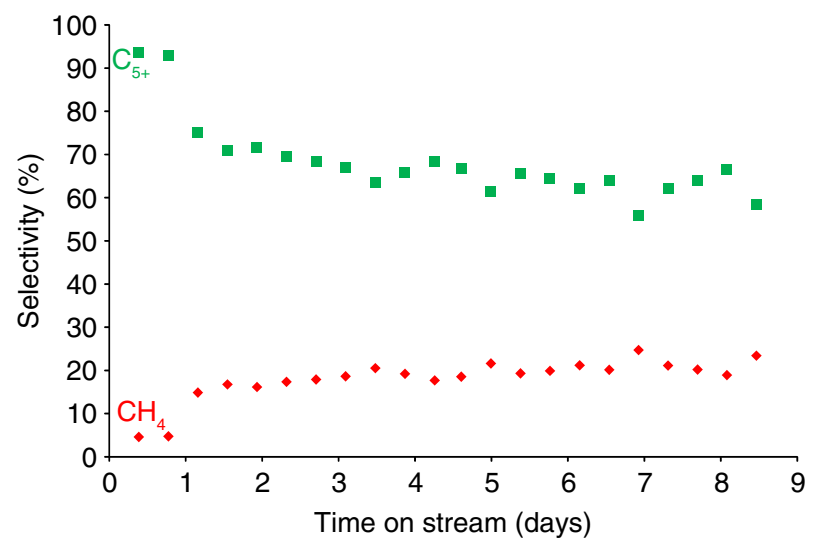

Figure 5

Methane $(\bullet)$ and $\mathrm{C}_{5+}(\boldsymbol{\square})$ selectivity versus time on stream over $\mathrm{PtCo} /$ silica catalyst. $220^{\circ} \mathrm{C}, 6$ bar, $\mathrm{H}_{2} / \mathrm{CO}=2$.

a value of $11 \%$ at the beginning of the reaction to around $10 \%$ after nine days on stream. A part of these important variations of $\mathrm{CO}$ conversion may probably be linked to classical experimental errors which are accentuated by the fact that operando cells are not ideal reactors [9-11]. After 5 days on stream, the conversion is less oscillating but is globally decreasing, which seems to reveal a catalyst deactivation.

At the end of the test, the TOF was estimated around $7.8 \mathrm{mmol}_{\mathrm{CO}} \cdot \mathrm{mol}_{\mathrm{Cosurf}}{ }^{-1} \cdot \mathrm{s}^{-1}$. Taking into account a reduction degree of $90 \%$, corrected TOF value was as high as $8.7 \mathrm{mmol}_{\mathrm{CO}} \cdot \mathrm{mol}_{\mathrm{Cosurf}}{ }^{-1} \cdot \mathrm{s}^{-1}$. Both are in the range of those reported for cobalt catalysts in similar conditions [17, 19].

Figure 5 shows methane and $\mathrm{C}_{5}$ - selectivity as a function of time on stream.

From these results it is obvious that the selectivity in $\mathrm{C}_{5+}$ products of interest decreased from more than $90 \%$ at the beginning of the reaction to less than $60 \%$ after 9 days on stream. The most important decrease occurred during the first day of the reaction with a drop from 93 to $75 \%$. The decrease is then slower and quite linear till the end of the test. This decrease in $\mathrm{C}_{5}$ - selectivity is parallel to an increase in methane selectivity from $5 \%$ at the beginning of the reaction to $23 \%$ at the end of the test. Again, these results are in good agreement with those reported for similar catalysts in similar conditions [17, 20, 21].

Selectivity and TOF in the range of usual results obtained with classical catalytic studies allow to consider that the reaction cell is suitable for operando studies. 


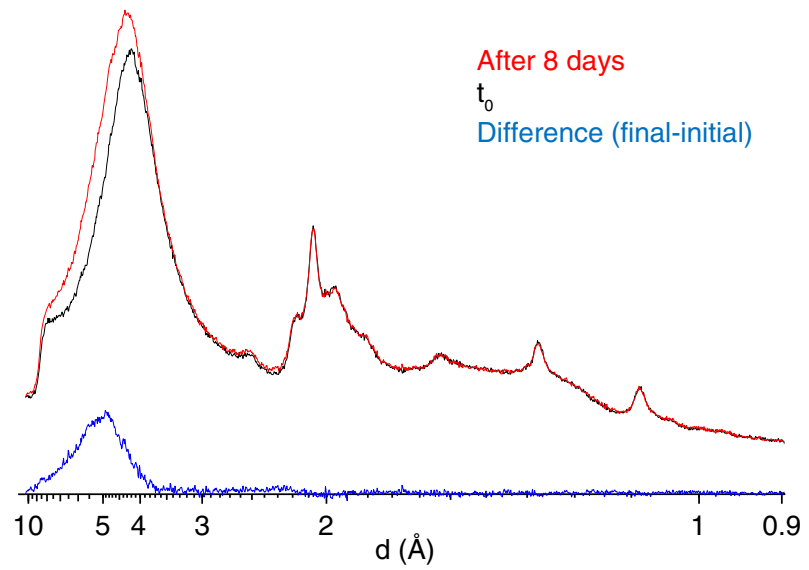

Figure 6

Operando XRD pattern of the $\mathrm{PtCo} /$ silica catalyst recorded before reaction and after 8 days on stream at $220^{\circ} \mathrm{C}, 6$ bar, $\mathrm{H}_{2} / \mathrm{CO}=2$.

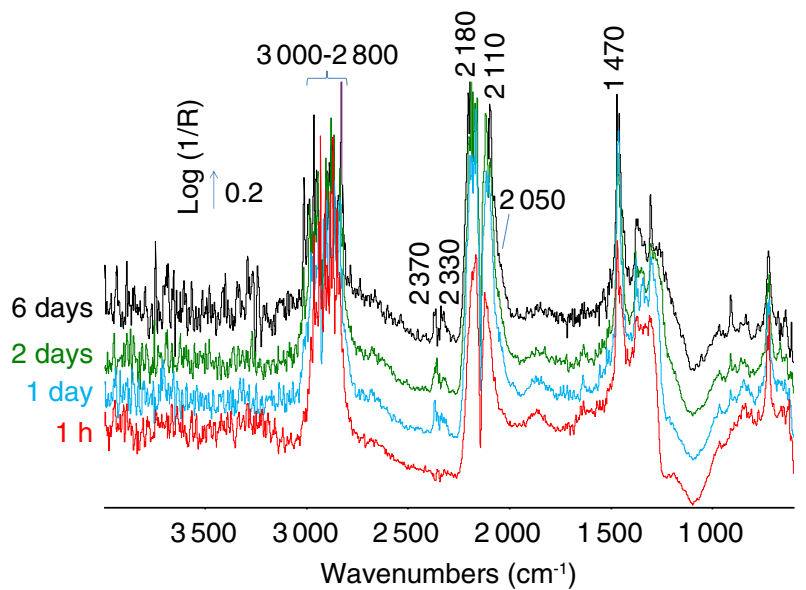

Figure 7

Operando DRIFTS spectra obtained over the $\mathrm{PtCo} /$ silica catalyst at different time on stream, at $220^{\circ} \mathrm{C}, 6$ bar, $\mathrm{H}_{2} / \mathrm{CO}=2$.

\subsection{Operando XRD}

Operando XRD allowed monitoring the evolution of the catalyst structure during the reaction and as exhibited in Figure 6 no crystalline phase change was observed during the test.

The proportion of fcc and hcp metal cobalt phases was not modified at all. No sintering was nor observed, the width of the diffraction peaks assigned to metal cobalt being obviously constant with time on stream. No new crystalline phase appeared during the reaction. In particular, no cobalt oxide such as $\mathrm{CoO}$, cobalt carbide such as $\mathrm{Co}_{2} \mathrm{C}$ or cobalt-silica species such as $\mathrm{Co}_{2} \mathrm{SiO}_{4}$ were observed. It is however not impossible that some of these species were formed in small amounts below the XRD detection limit $(<5 \%)$. If formed in some minor extent at the surface of the catalyst, such species would not be detectable with XRD technique whereas they could likely be involved in catalyst deactivation.

The only new diffraction peak clearly observed was centered at $5 \AA$ and could be assigned to wax in the pores of the catalyst and on its surface.

\subsection{Operando DRIFTS}

Operando DRIFTS allowed monitoring the evolution of the surface of the catalyst during the reaction (Fig. 7).

Various infrared bands corresponding to various species appeared and evolved with time on stream. The bands at 2180 and $2110 \mathrm{~cm}^{-1}$ are assigned to gaseous
$\mathrm{CO}[11,22]$ flowing through the reaction cell. These bands appeared ten minutes after the switch between the $\mathrm{N}_{2}$ flow and the syngas $\left(\mathrm{H}_{2}+\mathrm{CO}\right)$ flow, and increased until $\mathrm{N}_{2}$ was completely removed from the cell. After few hours, the $\mathrm{CO}$ bands reached a maximum and stable level, indicating that the $\mathrm{CO}$ concentration in the cell was stabilized, at the expected CO partial pressure of 2 bar.

The shoulder appearing at the early edge of the reaction at around $2050 \mathrm{~cm}^{-1}$ can be assigned to linear carbonyls on metal cobalt or platinum [9, 11, 22]. Its intensity seems to decrease slightly with time on stream, but this apparent decrease could also be a simple mathematical effect due to the concomitant global decrease of the bands assigned to silica, especially those at 1990,1865 and $1630 \mathrm{~cm}^{-1}$ related to Si-O bond vibration (Fig. 8). The evolution of carbonyls species can be observed more easily after subtraction of the spectrum of the catalyst obtained after reduction (Fig. 9).

The band of very low intensity in the $1900-2000 \mathrm{~cm}^{-1}$ region could be assigned to bridged carbonyls [9, 11, 22]. This band is however visible only during the first hours of the reaction, before disappearing or being flooded in the major decrease of the silica bands between 1990 and $1630 \mathrm{~cm}^{-1}$.

New bands also appeared in the $2800-3000 \mathrm{~cm}^{-1}$ region. These bands can be assigned to various methyl and methylene groups belonging to various hydrocarbons formed at the surface of the catalyst during the reaction. The sharp band at $1470 \mathrm{~cm}^{-1}$ can also be assigned to these species. 


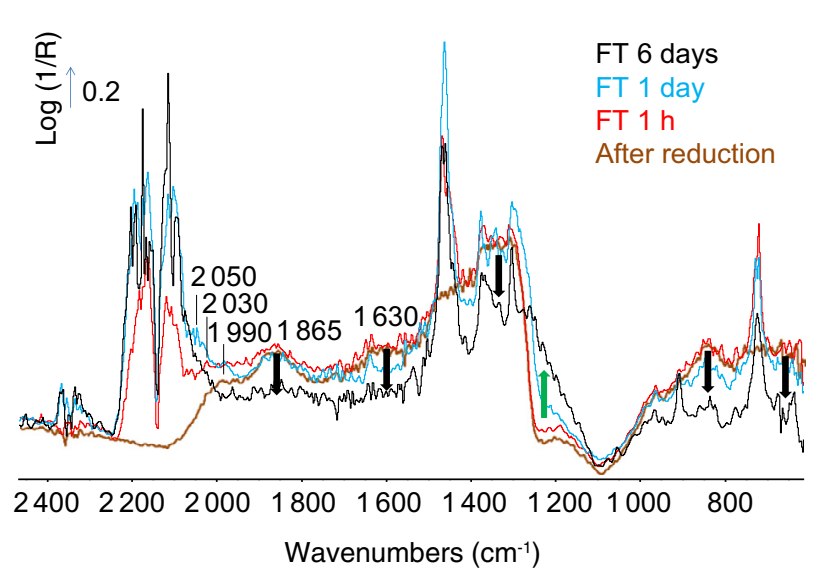

Figure 8

Operando DRIFTS spectra obtained over the PtCo/silica catalyst at different time on stream, at $220^{\circ} \mathrm{C}, 6$ bar, $\mathrm{H}_{2} / \mathrm{CO}=2$. Zoom in the $2500-700 \mathrm{~cm}^{-1}$ region, after subtraction of a reference spectrum of 1 bar of pure $\mathrm{CO}$.

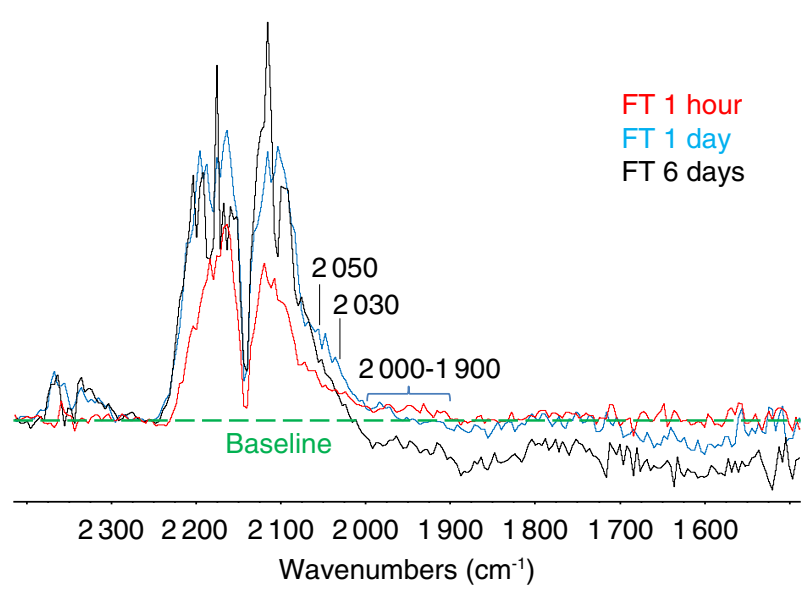

Figure 9

Operando DRIFTS spectra after subtraction of the spectrum recorded after reduction and of a reference spectrum of 1 bar of pure $\mathrm{CO}$.
Note that no methane, with its typical bands at 3015 and $1305 \mathrm{~cm}^{-1}[11,22]$, was detected inside the reaction cell, which is a good indication that the operando cell behaves as expected in a similar way as a fixed-bed reactor, without major products retrodiffusion.

The bands at 2370 and $2330 \mathrm{~cm}^{-1}$ can be assigned to $\mathrm{CO}_{2}$, more likely from the outside atmosphere of the laboratory $[9,11]$. Some $\mathrm{CO}_{2}$ was however produced during the test, but in very low quantity, as shown by $\mathrm{GC}$ data from which the selectivity in $\mathrm{CO}_{2}$ was estimated below $0.1 \% . \mathrm{CO}_{2}$ formation could result from the water gas shift reaction as well as from the Boudouard reaction [11].

During the test, the intensities of the bands assigned to the silica support were decreasing, especially after one day on stream, as illustrated in Figure 8. This decrease is a direct evidence that the catalyst is more and more covered by new species. Among them, adsorbed hydrocarbons can be responsible for this covering, since they are observed on the operando spectra. However, the areas of the corresponding bands in the $3000-2800 \mathrm{~cm}^{-1}$ region are quite stable after few hours on stream, whereas the areas of the various combination bands assigned to silica are mostly decreasing after one day on stream. This could mean that other species are at the surface of the catalyst although they are not detected with IR spectroscopy. Those species are likely infrared transparent, such as atomic carbon, amorphous polymeric carbon, graphene or graphite. Carbon formation was indeed suspected by several authors to be responsible for catalyst deactivation [5]. However, no graphite was detected on the operando X-Ray patterns. If really formed, graphite should thus be present in very low quantities of few layers at the surface of the catalyst.

The formation of graphene, considered as a single layer of graphite, could even more easily explain both the decrease in the intensity of the silica bands on the DRIFTS spectra and the absence of any typical diffraction peak on the X-Ray diagrams. The graphene formation mechanism described by Weststrate et al. in the case of ethylene adsorption on cobalt could also be very relevant in Fischer-Tropsch conditions [23].

Whatever the real identity of the species covering the surface of the catalyst, they could likely induce changes in the catalytic behavior of the catalyst. In particular, it is worth noting that the decrease in the IR bands assigned to silica occurred at the same time as did the decrease in $\mathrm{C}_{5+}$ selectivity in favor of methane selectivity. This supports the idea of graphene islands at the surface of the catalyst, changing the accessibility of the active sites and subsequently selectivity.

\section{CONCLUSIONS}

An innovative XRD-DRIFTS apparatus was developed to carry out operando studies combining simultaneously XRD and DRIFTS characterizations of catalysts under Fischer-Tropsch representative conditions. A PtCo/ silica catalyst was tested to evaluate the performances 
of this prototype. The catalytic properties shown during the Fischer-Tropsch synthesis at $220^{\circ} \mathrm{C}$ under 6 bar were in the same range of those already reported in the literature for similar catalysts in similar conditions, which confirmed the good behavior of the reaction cell, acting as a fixed-bed reactor with minimized diffusion problems. Operando X-Ray diffraction patterns did not show any bulk oxidation of cobalt, nor any change in the structure of the catalyst, nor sintering, nor any formation of any other crystalline compound, but showed the filling up of the pores of the catalyst with formed waxes. Operando DRIFT spectra showed the formation of various species at the surface of the catalyst and their evolution with time on stream. Adsorbed hydrocarbons species were directly observed at the surface which was also proposed to be covered with infrared transparent species such as polymeric carbon. The formation of the latter was suggested to be a possible cause of the decrease in the $\mathrm{C}_{5+}$ selectivity observed after one day on stream.

\section{ACKNOWLEDGMENTS}

Daniela Gaspar is acknowledged for the synthesis of the $\mathrm{PtCo} /$ silica catalyst.

\section{REFERENCES}

1 Ellis P.R., James D., Bishop P.T., Casci J.L., Lok C.M., Kelly G.J. (2010) Synthesis of High Surface Area Cobalt-onAlumina Catalysts by Modification with Organic Compounds, in Chemical Industries: Advances in Fischer-Tropsch Synthesis, Catalysts, and Catalysis, Davis B.H, Occelli M.L. (eds), CRC Press, Taylor \& Francis Group, Boca Raton, New York, Oxon.

2 De la Osa A.R., De Lucas A., Diaz-Maroto J., Romero A., Valverde J.L., Sanchez P. (2012) FTS fuels production over different Co/SiC catalysts, Catalysis Today 187, 173-182.

3 De la Peña O'Shea V.A., Homs N., Fierro J.L.G., Ramirez de la Piscina P. (2006) Structural changes and activation treatment in a $\mathrm{Co} / \mathrm{SiO}_{2}$ catalyst for Fischer-Tropsch synthesis, Catalysis Today 114, 422-427.

4 Van Santen R.A., Ciobica I.M., Van Steen E., Ghouri M.M. (2011) Mechanistic Issues in Fischer-Tropsch Catalysis, in Advances in Catalysis, B.C. Gates, H. Knözinger (eds), Academic Press, Burlington.

5 Saib A.M., Moodley D.J., Ciobica I.M., Hauman M.M., Sigwebela B.H., Weststrate C.J., Niemantsverdriet J.W., Van de Loosdrecht J. (2010) Fundamental understanding of deactivation and regeneration of cobalt Fischer-Tropsch synthesis catalysts, Catalysis Today 154, 271-282.

6 Van de Loosdrecht J., Balzhinimaev B., Dalmon J.A., Niemantsverdriet S.V., Tsybulya S.V., Saib A.M., Van Berge P.J., Visagie J.L. (2007) Cobalt Fischer-Tropsch synthesis: Deactivation by oxidation? Catalysis Today 123, 293-302.
7 Pena D., Griboval-Constant A., Diehl F., Lecocq V., Khodakov A.Y. (2013) Agglomeration at the Micrometer Length Scale of Cobalt Nanoparticles in AluminaSupported Fischer Tropsch Catalysts in a Slurry Reactor, Chem. Cat. Chem. 5, 728-731.

8 Pena D., Griboval-Constant A., Lecocq V., Diehl F., Khodakov A.Y. (2013) Influence of operating conditions in a continuously stirred tank reactor on the formation of carbon species on alumina supported cobalt FischerTropsch catalysts, Catalysis Today 215, 43-51.

9 Scalbert J., Meunier F.C., Daniel C., Schuurman Y. (2012) An operando DRIFTS investigation into the resistance against $\mathrm{CO}_{2}$ poisoning of a $\mathrm{Rh}$ /alumina catalyst during toluene hydrogenation, Phys. Chem. Chem. Phys. 14, 2159-2163.

10 Meunier F.C. (2010) The design and testing of kineticallyappropriate operando spectroscopic cells for investigating heterogeneous catalytic reactions, Chem. Soc. Rev. 39, $4602-4614$.

11 Scalbert J. (2012) New advances in the understanding of catalytic reactions involving biomass-derived model compounds, PhD Thesis, Université de Caen Basse Normandie, France

12 Braconnier L., Clémençon I., Legens C., Moizan V., Diehl F., Pillière H., Echegut P., De Sousa Meneses D., Schuurman Y. (2013) An X-Ray diffractometer coupled with diffuse reflectance infrared Fourier transform spectroscopy and gas chromatography for in situ and in operando characterization: an innovative analytical laboratory instrument, J. Appl. Cryst. 46, 262-266.

13 Borg O., Dietzel P., Spjelkavik A., Tveten E., Walmsley J., Diplas S., Eri S., Holmen A., Rytter E. (2008) FischerTropsch synthesis: Cobalt particle size and support effects on intrinsic activity and product distribution, J. Catal. 259, 161-164.

14 Sirita J., Phanichphant S., Meunier F.C. (2007) Quantitative analysis of adsorbate concentrations by diffuse reflectance FT-IR, Anal. Chem. 79, 3912-3918.

15 Elezovic N.R., Babic B.M., Radmilovic V., Gajic-Krstajic L.M., Krstajic N.V., Vracar L.M. (2011) A novel platinum-based nanocatalyst at a niobia-doped titania support for the hydrogen oxidation reaction, J. Serb. Chem. Soc. 76, 8, 1139-1152.

16 Chernavskii P.A., Pankina G.V., Lermontov A.S., Lunin V.V. (2003) Size Distribution of Cobalt Particles in Catalysts for the Fischer-Tropsch Synthesis, Kinetics and Catalysis 44, 5, 657-661.

17 Den Breejen J.P., Radstake P.B., Bezemer G.L., Bitter J.H., Froseth V., Holmen A., De Jong K.P. (2009) On the Origin of the Cobalt Particle Size Effects in Fischer-Tropsch Catalysis, J. Am. Chem. Soc. 131, 7197-7203.

18 Ducreux O., Rebours B., Roy-Auberger M., Bazin D. (2009) Microstructure of Supported Cobalt FischerTropsch Catalysts, Oil Gas Sci. Technol. 64, 1, 49-62.

19 Iglesia E. (1997) Design, synthesis, and use of cobaltbased Fischer-Tropsch synthesis catalysts, Appl. Catal. A 161, 59-78.

20 Karaca H., Safonova O.V., Chambrey S., Fongarland P., Roussel P., Griboval-Constant A., Lacroix M., Khodakov A.Y. (2011) Structure and catalytic performance of Ptpromoted alumina-supported cobalt catalysts under realistic conditions of Fischer-Tropsch synthesis, J. Catal. 277, 14-26. 
21 Diehl F., Khodakov A.Y. (2009) Promotion of Cobalt Fischer-Tropsch Catalysts with Noble Metals: a Review, Oil Gas Sci. Technol. 64, 11-24.

22 Sanchez-Escribano V., Larrubia Vargas M.A., Finocchio E., Busca G. (2007) On the mechanisms and the selectivity determining steps in syngas conversion over supported metal catalysts: an IR study, Appl. Catal. A 316, $68-74$.
23 Weststrate C.J., Kizilkaya A.C., Rossen E.T., Verhoeven M.W., Ciobica I.M., Saib A.M., Niemantsverdriet J.W. (2012) Atomic and Polymeric Carbon on Co(0001): Surface reconstruction, Graphene Formation, and Catalyst Poisoning, J. Phys. Chem. C 116, 11575-11583.

Manuscript submitted in April 2014 Manuscript accepted in June 2014

Published online in November 2014

Cite this article as: J. Scalbert, I. Clémençon, C. Legens, F. Diehl, D. Decottignies and S. Maury (2015). Development of an Innovative XRD-DRIFTS Prototype Allowing Operando Characterizations during Fischer-Tropsch Synthesis over Cobalt-Based Catalysts under Representative Conditions, Oil Gas Sci. Technol 70, 3, 419-428. 